\title{
EMPLOYEE ENGAGEMENT IN TOURISM: A GENERATIONAL STUDY OF EUROPEAN COUNTRIES
}

\author{
Pedro Ferreira* \\ Universidade Portucalense. Oporto \\ https://orcid.org/0000-0002-6506-7869
}

\begin{abstract}
The goal of this paper is to examine employee engagement among different generations of tourism workers across European countries. The research takes a quantitative approach. Data from 2,393 employees from 35 European countries working in tourism were considered. Data analysis was based on cluster analysis to find patterns of engagement across countries and hierarchical multiple regression analysis and other statistical tools to confirm differences between generations. The results reveal three groups of countries with different patterns of engagement. The findings also show differences between generational groups.
\end{abstract}

Keywords: Employee engagement; Generations; Baby boomers, Generation X; Generation Y; Europe.

\section{Compromiso de los empleados en el turismo: un estudio generacional de los países europeos}

\section{RESUMEN}

El objetivo de este documento es examinar el compromiso de los empleados entre las diferentes generaciones de trabajadores del turismo en los países europeos.

La investigación adopta un enfoque cuantitativo. Se consideraron datos de 2.393 empleados de 35 países europeos que trabajan en turismo. El análisis de datos se basó en el análisis de conglomerados para encontrar patrones de participación entre países y análisis jerárquico de regresión múltiple y otras herramientas estadísticas para confirmar las diferencias entre generaciones.

Fecha de recepción: 9 de mayo de 2019

Fecha de aceptación: 22 de enero de 2020

* Universidade Portucalense, Research on Economics, Management and Information Technologies REMIT. Rua Dr. António Bernardino de Almeida, 541. 4200-072 PORTO (Portugal). E-mail: pferreira@upt.pt 
Los resultados revelan tres grupos de países con diferentes patrones de compromiso. Los resultados también muestran diferencias entre los grupos generacionales.

Palabras clave: Compromiso de los empleados; Generaciones; Baby boomers, Generación X; Generación Y; Europa.

\section{INTRODUCTION}

Employee engagement is one of the most studied and used concept in human resources in the $21^{\text {st }}$ century. Since early scientific developments from Kahn (1990) and further dissemination to the practitioner context, mainly by the Gallup Group, the concept of engagement became very popular.

Engagement is considered to influence several individual and organizational outcomes, such as job involvement, intention to quit and organizational citizenship behaviour (Alfes, Shantz, Truss \& Soane, 2013; Ram \& Prabhakar, 2011; Saks, 2006), psychological/physical health, proactive organizational behaviour (Shimazu et al., 2008), among others.

Although engagement is presented as an employee behavioural outcome relevant for every type of business, it is in services that engagement becomes highly relevant. In fact, the quality of services tends to be highly dependent on the characteristics and behaviours of employees, which often deliver the service. The personal interaction between employees and customers - the service encounter - in frontline service businesses has been considered for some time a focal point of customer evaluations (Bettencourt \& Gwinner, 1996).Tourism and hospitality are a good example of the importance of the human factor for the quality of the service provided, in such a way that employees' behaviours can indirectly influence financial results of companies, through customer satisfaction (Chi \& Gursoy, 2009).

Although some studies have examined engagement in tourism and hospitality (Karatepe \& Olugbade, 2009; Lee, Kim \& Kim, 2013; Menguc, Auh, Yeniaras \& Katsikeas, 2017; Park \& Gursoy, 2012; Uludag \& Yaratan, 2010), none has examined the differences between generations at national level. Thus, this paper aims to examine the differences in engagement between generations and to identify possible similarities or differences in generational engagement across Europe in the tourism sector. For this purpose, data from the sixth wave of the European Working Conditions Survey will allow a quantitative and cross-sectional approach to the subject.

\section{LITERATURE REVIEW}

\subsection{The conceptualization of work engagement}

One of the first conceptualizations of engagement is attributed to Kahn(1990) that considered engagement as a combination of self and task, allowing "people who are personally engaged [to] keep their selves within the role, without sacrificing one for the other" (p. 700). More recently, the most popular conceptualization, alongside with grounded theo- 
retical and empirical development, was made by Schaufeli and his colleagues (Bakker \& Schaufeli, 2008; Balducci, Fraccaroli, \& Schaufeli, 2010; Schaufeli, Salanova, GonzalezRoma \& Bakker, 2002; Schaufeli, Shimazu, Hakanen, Salanova \& De Witte, 2017).

Based on previous studies about burnout (Bakker, Demerouti, \& Schaufeli, 2002; Taris, Le Blanc, Schaufeli \& Schreurs, 2005) employee engagement is considered the opposite psychological state and is defined as a fulfilling state of mind positively characterised by absorption, dedication and vigour (Schaufeli et al., 2002). This definition highlights the three dimensions of engagement. Vigour refers to the mental resilience and energy of high level during work. Dedication is understood as having enthusiasm, pride, significance, and challenge. While the term absorption refers to a state of being fully and deeply immersed in one's work.

Shuck and Wollard(2010), using an integrated literature review approach, developed a very comprehensive review of the topic, suggesting that engagement can be defined as "an individual employee's cognitive, emotional, and behavioural state directed toward desired organizational outcomes" (p. 103). According to the authors, this definition would overcome some of the inconsistencies found in previous definitions of seminal works, while offering clarity and being comprehensible for both practitioners and academics.

In a subsequent paper, Brad Shuck (2011)proposed to map the widely disparate approaches to employee engagement, thus offering a theoretical organisation of the concept. Four main streams were identified and described: (a) Kahn's need-satisfying approach(Kahn, 1990), (b)Maslach et al.'s burnout-antithesis approach (Maslach, Schaufeli \& Leiter, 2001), (c) Harter et al.'s satisfaction-engagement approach (Harter, Schmidt \& Hayes, 2002), and (d) Saks's multidimensional approach (Saks, 2006) (for details see Shuck, 2011). However diverse in definition and methodology all the approaches argue for positive outcomes at individual and organizational levels.

Although a relatively recent concept, employee engagement has been considered one of the most relevant antecedents of several individual and organizational outcomes. Among the most studied consequences, employee engagement seems to influence job satisfaction (Ferreira \& Rodrigues, 2018; Harter et al., 2002), organizational commitment (Saks, 2006), intention to quit and organizational citizenship behaviour (Alfes et al., 2013).

But the impact of employee engagement is not only confined to individual and behavioural outcomes. Some research also points out the positive impact of employee engagement on performance (Balducci et al., 2010; Chung \& Angeline, 2010; Harter et al., 2002), on customer satisfaction ratings and increased revenue (Vance, 2006; Wagner \& Harter, 2006), and on corporate social responsibility (Ferreira \& de Oliveira, 2014).

If the outcomes of employee engagement make the concept relevant for researchers and practitioners, no less important are the drivers of engagement. The most relevant factors leading to an increased engagement have been found mainly inside the organisation context, such as job resources and characteristics (Bakker, Hakanen, Demerouti \& Xanthopoulou, 2007; Chung \& Angeline, 2010; Cooper-Thomas, Xu \& Saks, 2018), meaningful work (Fairlie, 2011), organisational support, rewards and recognition and justice (Ram \& Prabhakar, 2011).This means that organizations have an important role to play when it comes to create the conditions to foster employee engagement. 


\subsection{Work engagement in tourism and hospitality}

Research on work engagement in tourism is not very different in nature from that in other areas. Following the analysis of Shuck (2011), research on work engagement in tourism and hospitality is widely disparate, following diverse approaches, either theoretical and methodological. However, despite the diversity of approaches to employee engagement, the findings are consensual about the relevance and importance, either direct or indirect, of employee engagement for companies' outcomes and performance.

For example, Karatepe and Olugbade (2009) following a resources approach test the impact of job (supervisor support) and personal resources (trait competitiveness and self-efficacy) on work engagement among frontline hotel employees. The results show that trait competitiveness predicted work engagement better than did self-efficacy, while supervisor support had no significant effect. Based on a different theoretical framework, namely the social exchange theory, Lee et al. (2013) examined how internal branding helps service organizations achieve desirable outcomes such as job satisfaction and employee loyalty. By developing a model based on internal branding, employee engagement, job satisfaction, and employee loyalty, the study supports the centrality of employee engagement, not only as an outcome of internal branding, but also as a mediator between internal branding and job satisfaction.

Several studies simultaneously examine the drivers and outcomes of employee engagement, placing engagement as a mediator. The relations tested involve individual and work related factors, and work and employee related outcomes. A study with hospitality frontline employees found that perceived role benefit, job autonomy, and strategic attention were all significantly related to greater employee engagement, which in turn was positively associated with innovative work behaviour (Slåtten \& Mehmetoglu, 2011).

Using a similar sample of participants, namely frontline hotel staff, Paek, Schuckert, Kim, and Lee(2015) examined work engagement as a partial mediator of the effect of psychological capital on employee morale. They found that front-line employees with higher levels of psychological capital are more engaged with their work and more likely to display job satisfaction and affective organizational commitment.

A different study (Jung \& Yoon, 2016) examined the relation between meaningful work and organizational commitment, when mediated by job engagement. Again, the results indicate that employees' meaning of work (work centrality, interpersonal relations, economic orientation, and obligation norms) positively influences their job engagement and organizational commitment.

\subsection{Generations and work engagement}

A generation can be defined as a group of people of the same age cohort that experience the same life events during the development life-stage. While experiencing those events, generational members are exposed to certain phenomenon and historical happenings on social and cultural terrains, which become the factors that influence their attitudes and thinking, and consequently affect their behaviour (Kupperschmidt, 2000). 
Although there is no clear agreement on the limits of age cohorts, Baby Boomers can be defined as individuals born between 1946 and 1964, Generation X is made of individuals born between 1965 and 1980 and Generation Y represents those born between 1981 and 1999 (Chawla, Dokadia \& Rai, 2017; Hoole \& Bonnema, 2015; Park \& Gursoy, 2012).

Despite the growing volume of research conducted in the last two decades on employee engagement, there is not much empirical research examining generational differences in employee engagement, even more with tourism and hospitality employees. Even though, the pattern that emerges from previous studies is the higher level of engagement of Baby boomers and the lowest level of engagement of Generation Y. Moreover, the difference between Baby Boomers and other generational cohorts is systematically significant, while the difference between Generation X and Generation Y does not present a clear pattern.

Chawla et al. (2017) examined multigenerational differences in career preferences, reward preferences and work engagement using a sample of employees of moderate to large Indian organizations. Among other findings, work engagement is significantly different between the three examined generations (senior generation, generation $\mathrm{X}$ and generation Y). Specifically, they found that the senior generation (equivalent to baby boomers) presented a significantly higher level of engagement, while generation $\mathrm{Y}$ presented the lower level of engagement.

Hoole and Bonnema (2015) conducted a study with South African employees in order to examine whether there are significant variances between the levels of work engagement and meaningful work between different generational cohorts. Similarly to Chawla et al.(2017) study, Baby boomers presented the highest level of engagement and Generation $\mathrm{Y}$ the lowest. Significant differences were found between Baby Boomers and Generation $\mathrm{X}$ and Baby Boomers and Generation Y, but no significant difference between Generation $\mathrm{X}$ and Generation Y.

Park and Gursoy (2012) conducted a study with customer contact employees of a North American branded hotel management company, with the goal of examining work engagement of three generational cohorts. The results suggest that employees in the older generations are likely to be more dedicated to, engrossed in, and even vigorous at work. These findings indicate that employees of younger generations, in particular Generation Y employees, have a lower level of work engagement than do older generations.

\section{METHODS}

The data used in this study was taken from the most recent wave - the sixth wave (2015) - of the European Working Conditions Survey (EWCS) promoted by the European Foundation for the Improvement of Living and Working Conditions (Eurofound). Fieldwork was conducted in the period of February-December 2015. In total, 43,850 individual workers were interviewed in face-to-face interviews in their own homes.

The Eurofound was set up by the European Council, with the aim of contributing to the planning and design of better living and working conditions in Europe. Its mission is to provide information, advice and expertise for key actors in the field of EU social policy on subjects such as living and working conditions, industrial relations and managing change in Europe, on the basis of comparative information, research and analysis. 
Among other regular pan-European surveys, Eurofound is responsible for the EWCS. The main goal of this survey is to provide an overview of working conditions throughout Europe, indicating the changes affecting the workforce and quality of work.

The survey aimed to provide an analysis of working conditions in the 28 EU Member States, Norway, Switzerland, Albania, the Former Yugoslav Republic of Macedonia, Montenegro, Serbia and Turkey, and included a wide range of issues such as work organisation, working time, equal opportunities, training, health \& safety and job satisfaction.

\subsection{Participants}

For the purpose of this study it will be considered only the employed population aged 15 years or older, working in the tourism sector. Usually, self-employed population is not subject to the constraints of an organization (hierarchy, procedures, processes, and so forth) when working without employees and most of the times work as liberal professionals. On the other hand, self-employed with employees are most of the times owners of micro or small enterprises and, because of that, are in a position that provides a high degree of autonomy.

Additionally, participants are workers from the tourism sector. The variable "sector of activity of the employer", based on the NACE classification, was used to isolate respondents working in the tourism sector. The total sample is made of 2,392 workers in the tourism and hospitality sector, ranging from 19 participants in Denmark to 303 participants in Spain. The average is 68 workers per country.

The data obtained captures the working conditions of European workers as they are perceived and reported by them. Thus, it should be noted that the information provided compiles workers' point of view, although several questions are directed to factual information, so that the gap between "reality" and "perceived reality" should be minor; in other cases, the respondents are asked to subjectively evaluate their situation which makes the problem of "reality vs. perception" irrelevant. Although arguable, this does not need to be considered a weakness, because in many cases, it's the perception effect that drives behaviours, not reality itself. In fact, Meyer and Allen (1997) observed that employees' perceptions of 'reality' are likely to influence their performance more than other formal contingencies. Thus, if a worker perceives he/she is unfairly paid, he/she may show dissatisfaction by asking for a raise, try to move to another job or show his/her dissatisfaction through behaviour in any other way.

\subsection{Measurements}

For the purpose of this research, the most important measures are generational cohorts and employee engagement. Generational cohorts were computed from the variable "age". As previously stated, the year bands of generational cohorts are not consensual. However, most of the literature defines generational cohorts as follows:

- Baby Boomers: 52 to 69 years old (born between 1946 to 1963)

- Generation X: 36 to 51 years old (born between 1964 to 1979) 
- Generation Y: 16 to 35 years old (born between 1980 to 1999)

Employee engagement was measured using Schaufeli's Utrecht Work Engagement Scale (UWES) (Schaufeli, Bakker, \& Salanova, 2006). The EWCS uses an ultra-short version of UWES recently introduced (Schaufeli et al., 2017), made of only three items, covering the basic three dimensions of engagement: "At my work I feel full of energy" (vigour), "I am enthusiastic about my job" (dedication), and "Time flies when I am working" (absorption). The items were measured using a 5-point Likert scale.

Following Schaufeli(2017), a mean value was computed resulting in three levels of engagement:

- Highly engaged $(>4.0)$

- Engaged (3.8-4.0)

- $\quad$ Little engaged $(<3.0)$

Table 1

DESCRIPTIVES OF ENGAGEMENT LEVELS

\begin{tabular}{|l|r|r|r|}
\hline & \multicolumn{1}{|c|}{ Frequency } & \multicolumn{1}{|c|}{ Percent } & Cumulative Percent \\
\hline Little engaged & 1017 & 42.5 & 42.5 \\
\hline Engaged & 850 & 35.5 & 78.1 \\
\hline Highly engaged & 525 & 21.9 & 100.0 \\
\hline Total & 2392 & 100.0 & \\
\hline
\end{tabular}

Demographic factors, including level of education, tenure, number weekly working hours, and company size were used as control variables. Level of education is based on ISCED classification. Tenure is based on the variable "how many years have you been on in your company or organization". Number of weekly working hours reports the total number of working hours in the participant's main job. Company size reports the number of employees in the participant's company or organization

\subsection{Sample}

The sample is made of 2,393 workers from the 35 countries. In terms of education, the majority $(52.5 \%)$ holds the upper secondary education. Workers with a higher education degree represent a little more of $10 \%$. About $69.3 \%$ work full-time with a contract of unlimited duration (58.4\%). The most represented occupation is related with service and sales $(62.9 \%)$, followed by elementary occupations $(14.9 \%)$ and managers $(11.3 \%)$.

\subsection{Statistical Analysis}

Statistical analysis starts by describing the levels of engagement in each country. The following step aims to identify possible statistically significant differences in employee 
engagement between the generational cohorts. Finally, in order to find possible patterns of employee engagement in Europe, a cluster analysis was performed.

A hierarchical multiple regression analysis was conducted. This analysis allowed highlighting the importance of generational cohorts for the level of engagement of tourism and hospitality workers. Engagement is computed as the dependent variable and generational cohorts is computed as the independent variable. The regression model is performed in two steps. The first step includes all the control variables, and the second step adds generational cohorts.

Cluster analysis is a multivariate technique that looks for interdependence between cases or observations, that is, seeks for a "natural structure" among observations, based on a given multivariate profile. This technique is similar to factor analysis, but while the latter aims to reduce data (variables), cluster analysis focuses on the clustering/grouping of cases or observations.

The key feature of cluster analysis is to preserve maximum internal homogeneity and maximum external heterogeneity. That is, cluster analysis works by grouping individuals or objects in clusters with very close similarities among them, while retaining a high degree of mismatch with objects or individuals of other clusters (Hair, Anderson, Tatham \& Black, 1999). Cluster analysis can be used for several purposes, such as describe taxonomies, simplification of data, and identification of relationships.

According to the description of the clustering method and the methodological framework adopted by recent studies on the subject, the procedure adopted in this study will be based on the use of hierarchical method using Ward's method of clustering cases and the Euclidean distance as a measure of dissimilarity. This method is well adjusted to exploratory cluster analysis, that is, when there is no previous number of clusters to be formed. Although it could be said that previous literature could inform the number of clusters, the fact is that these studies were based on different data, number of countries and variables. Since cluster analysis is highly sensible to new information - namely new variables and new cases (or countries in this case) - it is not advisable to use previous research as the basis to define the number of clusters to be extracted.

The first step was to perform an exploratory cluster analysis in order to determine the number of clusters. The decision was based on coefficients of the agglomeration schedule. The second step comprised a confirmatory cluster analysis. Again, the hierarchical method using Ward's method of clustering and the Euclidean distance as a measure of dissimilarity was used. However, in this case, a single solution with the number of clusters previously defined was saved. In both steps, cases were labelled according to the variable "country". This will allow understanding how European countries are grouped.

The following step was to examine the differences between clusters. This procedure highlights the differences between clusters regarding employee engagement scores and, thus, what are the main characteristics of each cluster. This step involves performing a one-way between-groups analysis of variance (ANOVA) to examine differences between means and their significance and a Tukey post-hoc test to determine where the differences lie. 


\section{FINDINGS}

The first table describes the general level of engagement within each country's tourism workers. The general level of engagement is quite low across European countries. Only Belgium is above $40 \%$ of highly engaged workers, while France (35.8\%), Ireland $(37 \%)$, FYROM (34\%) and Switzerland $(36.5 \%)$ are above $30 \%$. On the opposite, Portugal $(66.7 \%)$ presents the highest number of workers with low levels of engagement ("little engaged"), followed by Turkey (58.7\%), Albania (57.3\%), Greece (55\%), while several countries score between $40 \%$ and $55 \%$.

Table 2

ENGAGEMENT LEVEL BY COUNTRY

\begin{tabular}{|l|r|r|r|}
\hline \multirow{2}{*}{ Country } & \multicolumn{3}{|c|}{ Engagement Level } \\
\cline { 2 - 4 } Austria & Little engaged & Engaged & Highly engaged \\
\hline Belgium & $34.9 \%$ & $41.3 \%$ & $23.8 \%$ \\
\hline Bulgaria & $20.9 \%$ & $33.9 \%$ & $45.2 \%$ \\
\hline Croatia & $34.5 \%$ & $41.8 \%$ & $23.6 \%$ \\
\hline Cyprus & $43.8 \%$ & $43.8 \%$ & $12.5 \%$ \\
\hline Czech Republic & $49.1 \%$ & $36.0 \%$ & $14.9 \%$ \\
\hline Denmark & $49.0 \%$ & $37.3 \%$ & $13.7 \%$ \\
\hline Estonia & $47.4 \%$ & $31.6 \%$ & $21.1 \%$ \\
\hline Finland & $14.7 \%$ & $58.8 \%$ & $26.5 \%$ \\
\hline France & $30.0 \%$ & $46.7 \%$ & $23.3 \%$ \\
\hline Germany & $35.8 \%$ & $28.3 \%$ & $35.8 \%$ \\
\hline Greece & $42.5 \%$ & $41.4 \%$ & $16.1 \%$ \\
\hline Hungary & $55.0 \%$ & $28.8 \%$ & $16.2 \%$ \\
\hline Ireland & $34.1 \%$ & $46.3 \%$ & $19.5 \%$ \\
\hline Italy & $21.9 \%$ & $41.1 \%$ & $37.0 \%$ \\
\hline Latvia & $37.0 \%$ & $38.3 \%$ & $24.7 \%$ \\
\hline Lithuania & $47.6 \%$ & $35.7 \%$ & $16.7 \%$ \\
\hline Luxembourg & $28.1 \%$ & $46.9 \%$ & $25.0 \%$ \\
\hline Malta & $39.6 \%$ & $26.4 \%$ & $34.0 \%$ \\
\hline Netherlands & $28.6 \%$ & $44.4 \%$ & $27.0 \%$ \\
\hline Poland & $15.9 \%$ & $56.8 \%$ & $27.3 \%$ \\
\hline Portugal & $35.1 \%$ & $40.5 \%$ & $24.3 \%$ \\
\hline Romania & $66.7 \%$ & $23.3 \%$ & $10.0 \%$ \\
\hline Slovakia & $31.4 \%$ & $45.7 \%$ & $22.9 \%$ \\
\hline Slovenia & $43.5 \%$ & $45.7 \%$ & $10.9 \%$ \\
\hline Spain & $51.5 \%$ & $30.6 \%$ & $17.2 \%$ \\
\hline Sweden & $51.6 \%$ & $31.4 \%$ & \\
\hline & & & \\
\hline
\end{tabular}




\begin{tabular}{|c|c|c|c|}
\hline \multirow[b]{2}{*}{ Country } & \multicolumn{3}{|c|}{ Engagement Level } \\
\hline & Little engaged & Engaged & Highly engaged \\
\hline UK & $37.1 \%$ & $37.1 \%$ & $25.7 \%$ \\
\hline Montenegro & $54.5 \%$ & $31.2 \%$ & $14.3 \%$ \\
\hline FYROM & $26.4 \%$ & $39.6 \%$ & $34.0 \%$ \\
\hline Serbia & $53.8 \%$ & $20.5 \%$ & $25.6 \%$ \\
\hline Turkey & $58.7 \%$ & $26.0 \%$ & $15.3 \%$ \\
\hline Norway & $52.0 \%$ & $32.0 \%$ & $16.0 \%$ \\
\hline Switzerland & $29.7 \%$ & $33.8 \%$ & $36.5 \%$ \\
\hline Albania & $57.3 \%$ & $30.5 \%$ & $12.2 \%$ \\
\hline Total & $42.5 \%$ & $35.5 \%$ & $21.9 \%$ \\
\hline
\end{tabular}

The first goal was to examine the differences in engagement between generations. This goal was accomplished by performing a one-way between-groups analysis of variance (ANOVA).

Table 3

DIFFERENCES IN ENGAGEMENT BETWEEN GENERATIONS (ANOVA)

\begin{tabular}{|l|r|r|r|r|r|}
\hline & Sum of Squares & \multicolumn{1}{|c|}{ df } & Mean Square & F & \multicolumn{1}{c|}{ Sig. } \\
\hline Between Groups & 8.112 & 2 & 4.056 & 6.856 & .001 \\
\hline Within Groups & 1399.632 & 2366 & .592 & & \\
\hline Total & 1407.744 & 2368 & & & \\
\hline
\end{tabular}

The differences between generations are significant. Yers differ significantly from Boomers and Xers. The effect size is large (eta=0.76) (Cohen, 1998) offering a high degree of confidence.

Table 4

TUKEY TEST FOR THE DIFFERENCES BETWEEN GENERATIONAL COHORTS

\begin{tabular}{|c|c|c|c|c|c|c|}
\hline \multirow[b]{2}{*}{$\begin{array}{l}\text { (I) } \\
\text { Generations }\end{array}$} & \multirow[b]{2}{*}{$\begin{array}{l}(\mathrm{J}) \\
\text { Generations } \\
\end{array}$} & \multirow{2}{*}{$\begin{array}{c}\text { Mean } \\
\text { Difference } \\
(\mathrm{I}-\mathrm{J})\end{array}$} & \multirow[b]{2}{*}{$\begin{array}{l}\text { Std. } \\
\text { Error }\end{array}$} & \multirow[b]{2}{*}{ Sig. } & \multicolumn{2}{|c|}{ 95\% Confidence Interval } \\
\hline & & & & & $\begin{array}{l}\text { Lower } \\
\text { Bound }\end{array}$ & $\begin{array}{l}\text { Upper } \\
\text { Bound }\end{array}$ \\
\hline \multirow[t]{2}{*}{ Boomers } & Gen X & .04315 & .04722 & .632 & -.0676 & .1539 \\
\hline & Gen Y & $.14257^{*}$ & .04489 & .004 & .0373 & .2478 \\
\hline \multirow[t]{2}{*}{ Gen X } & Boomers & -.04315 & .04722 & .632 & -.1539 & .0676 \\
\hline & Gen Y & $.09941^{*}$ & .03514 & .013 & .0170 & .1818 \\
\hline \multirow[t]{2}{*}{ Gen Y } & Boomers & $-.14257^{*}$ & .04489 & .004 & -.2478 & -.0373 \\
\hline & Gen X & $-.09941^{*}$ & .03514 & .013 & -.1818 & -.0170 \\
\hline
\end{tabular}

* The mean difference is significant at the 0.05 level. 
A one-way between-groups analysis of variance was conducted to explore the impact of generations on levels of engagement, as measured by the short version of the UWES. Subjects were divided into three groups according to their age (Group 1: Boomers; Group 2: Xers; Group 3: Yers). There sultsshow a statistically significant difference at the $\mathrm{p}<.05$ level in engagement scores for the three generations $[\mathrm{F}(2,2356)=6.856, \mathrm{p}=.01]$. Despite reaching statistical significance, the actual difference in mean scores between the groups was relatively small. The effect size, calculated using eta squared, was $>.01$. Post-hoc comparisons using the Tukey HSD test indicated that the mean score for Yers $(\mathrm{M}=3.82, \mathrm{SD}=0.79)$ was significantly different from Boomers $(\mathrm{M}=3.96, \mathrm{SD}=0.70)$ and Xers $(\mathrm{M}=3.92, \mathrm{SD}=0.77)$. Boomers did not differ significantly from Xers.

\section{Figure 1}

\section{LEVEL OF ENGAGEMENT BY GENERATIONAL COHORT}

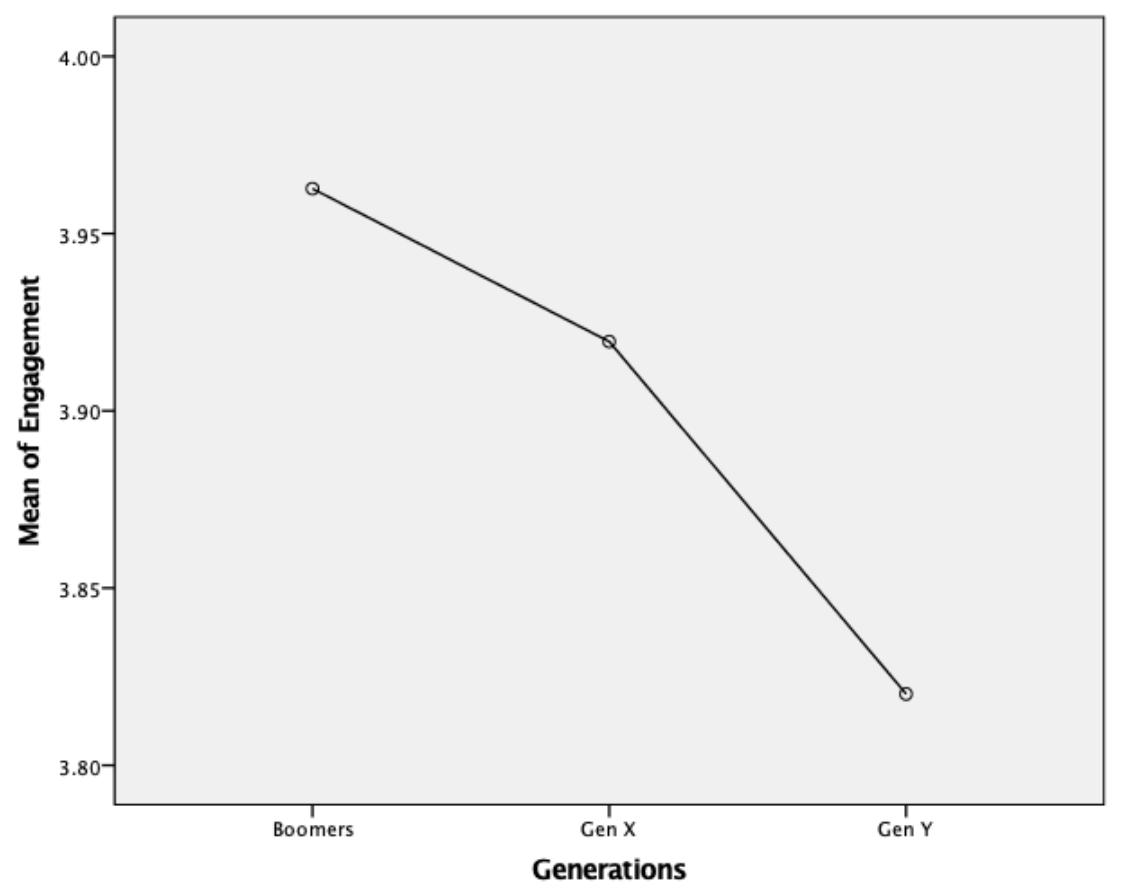

In order to support the evidence of statistical significant differences in levels of engagement between different generations, a hierarchical multiple regression model was performed. This analysis tests the influence of several demographic variables in the first step and the contribution of generational cohorts in the second step. 


\begin{tabular}{|l|l|r|r|r|r|r|r|}
\hline Step & \multicolumn{1}{|c|}{ Variables } & \multicolumn{1}{c|}{$\beta$} & \multicolumn{1}{c|}{$T$} & \multicolumn{1}{c|}{ Sig. } & \multicolumn{1}{c|}{$R^{2}$} & \multicolumn{1}{c|}{$\Delta R^{2}$} & \multicolumn{1}{c|}{$F$} \\
\hline 1 & Level of education & .068 & 3.091 & .002 & .007 & --- & 3.677 \\
\hline & Tenure & .034 & 1.554 & .120 & & & \\
\hline & Working hours & -.044 & -1.998 & .046 & & & \\
\hline & Company size & .009 & .426 & .670 & & & \\
\hline 2 & Level of education & .075 & 3.402 & .001 & .013 & .006 & 5.760 \\
\hline & Tenure & -.011 & -.451 & .652 & & & \\
\hline & Working hours & -.044 & -2.014 & .044 & & & \\
\hline & Company size & .015 & .682 & .495 & & & \\
\hline & Generations & -.094 & -3.742 & .000 & & & \\
\hline
\end{tabular}

The results of the regression analysis show that despite the statistical significant influence of level of education and working hours, generational cohorts have an important influence on the level engagement. Not only the $\mathrm{R}^{2}$ increases in the second step of the model, but also generational cohort has the higher unique contribution.

The second goal of this research was to examine possible similarities or differences in generational engagement across Europe. For this purpose, using hierarchical clustering, classification of countries according to the level of engagement of the generational cohorts shows 3 different groups of countries.

Group 1 is made of 16 countries, namely Austria; Bulgaria; Denmark; Finland; France; Italy; Latvia; Lithuania; Malta; Poland; Romania; Slovenia; Sweden; UK; Norway; Switzerland. This group presents high levels of engagement for Boomers and Xers, and the lower level of engagement for Yers across the 3 groups. This group also presents the biggest difference between Xers and Yers in engagement level.

Group 2 is made of only 5 countries (Belgium; Estonia; Ireland; Netherlands; FYROM) with the highest levels of engagement across all generational cohorts.

Finally, group 3 is made of 14 countries, namely Croatia; Cyprus; Czech Republic; Germany; Greece; Hungary; Luxembourg; Portugal; Slovakia; Spain; Montenegro; Serbia; Turkey; Albania. This group presents the lowest level of engagement across all generational cohorts.

Table 5

GROUPS OF COUNTRIES BY LEVEL OF ENGAGEMENT AND GENERATIONAL COHORT

\begin{tabular}{|l|l|r|r|r|}
\hline & \multicolumn{1}{|c|}{ Generational Cohort } \\
\hline Clusters & Countries & Boomers & Xers & Yers \\
\hline Group 1 & $\begin{array}{l}\text { Austria; Bulgaria; Denmark; Finland; France; Italy; Latvia; } \\
\text { Lithuania; Malta; Poland; Romania; Slovenia; Sweden; UK; } \\
\text { Norway; Switzerland }\end{array}$ & 4.14 & 4.07 & 3.84 \\
\hline Group 2 & Belgium; Estonia; Ireland; Netherlands; FYROM & 4.35 & 4.34 & 4.16 \\
\hline Group 3 & $\begin{array}{l}\text { Croatia; Cyprus; Czech Republic; Germany; Greece; Hungary; } \\
\text { Luxembourg; Portugal; Slovakia; Spain; Montenegro; Serbia; } \\
\text { Turkey; Albania }\end{array}$ & 3.99 & 3.96 & 3.86 \\
\hline
\end{tabular}


The post-hoc tests to test significant differences between groups indicate that the clusters are quite different. Differences between Boomers across clusters are statistically different, except for the differences between clusters 1 and $2(\mathrm{p}=.065)$. Regarding Yers the differences are also significant, except between clusters 1 and $3(p=.546)$. The differences between clusters for Xers are all significant.

\section{Figure 2 \\ LEVEL OF ENGAGEMENT BY GENERATIONAL COHORT}
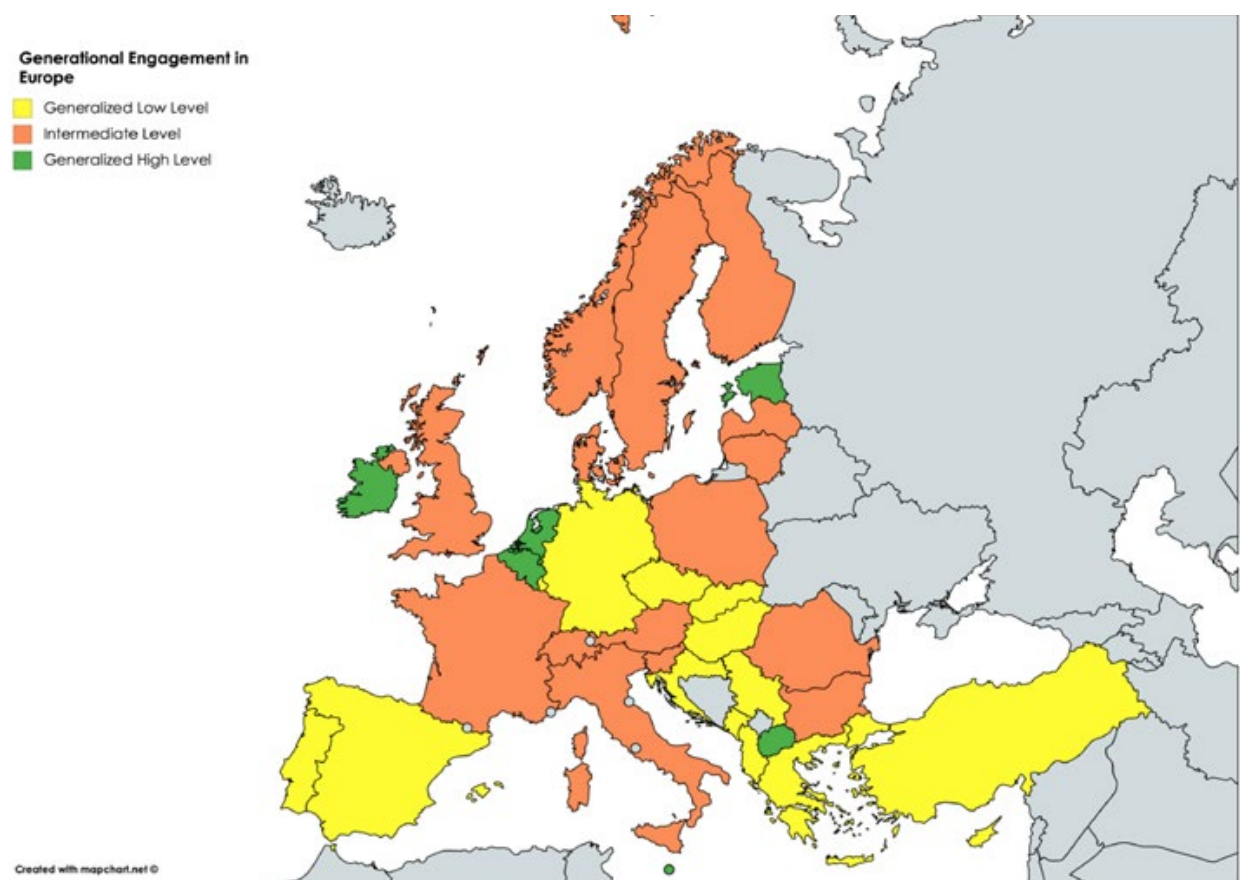

\section{DISCUSSION AND CONCLUSION}

The goal of this research was twofold, namely examine the differences in engagement between generations and to identify possible similarities or differences in generational engagement across Europe in the tourism sector.

For the first goal, it was showed that there are significant differences between generational cohorts, especially between Yers and the two previous generations. The younger generation presents lower levels of engagement when compared with Xers and Boomers. These results are supported by previous research on hospitality that show lower levels of engagement among Generation Y, when compared with older generations (Chawla et al., 2017; Hoole \& Bonnema, 2015; Park \& Gursoy, 2012).

However, it should be noted that in the present study Generation X and Baby Boomers show no statistically significant differences, which is contrary to the research of Hoole 
and Bonnema(2015). They found a significant difference between Generation X and Baby Boomers, but no difference between Generation X and Generation Y. In other words, in the present study, Generation X is closer to Baby Boomers than to Generation Y, while in the already mentioned study it's the opposite. One possible explanation for this discrepancy may lie on cultural differences. As Hoole \& Bonnema(2015) put it, as a result of conflicting results in examining generational cohorts at work, there may be potential cultural and regional influences on the development of engagement.

This latter suggestion of Hoole \& Bonnema (2015) finds support in the second goal of this study, since it was showed that European workers present different patterns of engagement. The cluster analysis revealed 3 different groups of countries with different patterns of engagement. Only a small group of countries present high levels of engagement, while the other two groups presented lower levels of engagement. The smaller cluster characterized by higher levels of engagement in all generations is composed of northern countries (with the exception of FYROM). The cluster with a generalized low level of work engagement is made of south and eastern countries (with the exception of Germany and Luxembourg).

This result is aligned with previous conclusions of Schaufeli(2017). He found engagement scores for Northern and Northwestern Europe to be more favourable, while Eastern and Southern Europe presented less favourable scores. As for the general population, the explanation for generational differences may be found in the economy, governance and culture. According to the study of Schaufeli(2017) more productivity, more GDP and less working hours, tend to raise levels of engagement; also, a country with less corruption and gender inequality, and more integrity and democracy in terms of governance tends to contribute positively for engagement; finally, in the cultural realm, less power distance and uncertainty avoidance, and more individualism and indulgence contribute to higher levels of engagement.

Alongside the findings and conclusions, this study contributes to raise some interesting topics to be further pursued in future research. For example, even if macro factors, such as the economy, governance and culture, help explain these results, what are the industry and organizational factors that might be influencing the levels of engagement found for each generation and cluster of countries.

\section{REFERENCES}

ALFES, K., SHANTZ, A.D., TRUSS, C. \& SOANE, E.C. (2013): «The link between perceived human resource management practices, engagement and employee behaviour : a moderated mediation model». The International Journal of Human Resource Management, vol. 24 (2), pp. 330-351.

BAKKER, A.B., \& SCHAUFELI, W.B. (2008): «Positive organizational behavior: engaged employees in flourishing organizations», Journal of Organizational Behavior, vol. 29, pp. 147-154.

BAKKER, ARNOLD B., DEMEROUTI, E. \& SCHAUFELI, W.B. (2002): «Validation of the Maslach Burnout Inventory - General Survey: An Internet Study», Anxiety, Stress \& Coping, vol. 15 (3), pp. 245-260. 
BAKKER, ARNOLD B., HAKANEN, J.J., DEMEROUTI, E. \& XANTHOPOULOU, D. (2007): «Job resources boost work engagement, particularly when job demands are high», Journal of Educational Psychology, vol. 99 (2), pp. 274-284.

BALDUCCI, C., FRACCAROLI, F. \& SCHAUFELI, W.B. (2010): «Psychometric Properties of the Italian Version of the Utrecht Work Engagement Scale (UWES-9)», European Journal of Psychological Assessment, vol. 26 (2), pp. 143-149.

BETTENCOURT, L.A. \& GWINNER, K. (1996): «Customization of the service experience: The role of the frontline employee», International Journal of Service Industry Management, vol. 7 (2), pp. 3-20.

CHAWLA, D., DOKADIA, A. \& RAI, S. (2017): «Multigenerational Differences in Career Preferences, Reward Preferences and Work Engagement among Indian Employees», Global Business Review, vol. 18 (1), pp. 181-197.

CHI, C.G. \& GURSOY, D. (2009): «Employee satisfaction, customer satisfaction, and financial performance: An empirical examination», International Journal of Hospitality Management, vol. 28 (2), pp. 245-253.

CHUNG, N.G. \& ANGELINE, T. (2010): «Does work engagement mediate the relationship between job resources and job performance of employees?», African Journal of Business Management, vol. 4 (9), pp. 1.837-1.843.

COHEN, J. (1998): Statistical power analysis for the behavioral sciences (2nd ed.). Hillsdale, NJ: Lawrence Earlbaum Associates.

COOPER-THOMAS, H.D., XU, J. \& SAKS, A. (2018): «The differential value of resources in predicting employee engagement», Journal of Managerial Psychology, vol. 33(4-5), pp. 326-344.

FAIRLIE, P. (2011): «Meaningful Work, Employee Engagement, and Other Key Employee Outcomes: Implications for Human Resource Development», Advances in Developing Human Resources, vol. 13 (4), pp. 508-525.

FERREIRA, P. \& DE OLIVEIRA, E.R. (2014): «Does corporate social responsibility impact on employee engagement?», Journal of Workplace Learning, vol. 26 (3), pp. 232-248.

FERREIRA, P. \& RODRIGUES, P. (2018): «Engagement as an antecedent of the satisfaction-performance relation : a study with line managers», International Journal of Human Resources Development \& Management, vol. 18 (1-2), pp. 32-50.

HAIR, J.F., ANDERSON, R., TATHAM, R. \& BLACK, D. (1999): Analisis Multivariante (5th ed.). Madrid, Prentice-Hall.

HARTER, J.K., SCHMIDT, F.L. \& HAYES, T.L. (2002): «Business-unit-level relationship between employee satisfaction, employee engagement, and business outcomes: A meta-analysis», Journal of Applied Psychology, vol. 87 (2), pp. 268-279.

HOOLE, C. \& BONNEMA, J. (2015): «Work engagement and meaningful work across generational cohorts», SA Journal of Human Resource Management, vol. 13 (1), pp. $1-11$.

JUNG, H.S. \& YOON, H.H. (2016): «What does work meaning to hospitality employees? The effects of meaningful work on employees' organizational commitment: The mediating role of job engagement», International Journal of Hospitality Management, vol. 53, pp. 59-68. 
KAHN, W.A. (1990): «Psychological Conditions of Personal Engagement and Disengagement at Work», Academy of Management Journal, vol. 33 (4), pp. 692-724.

KARATEPE, O.M. \& OLUGBADE, O.A. (2009): «The effects of job and personal resources on hotel employees' work engagement», International Journal of Hospitality Management, vol. 28 (4), pp. 504-512.

KUPPERSCHMIDT, B.R. (2000): «Multigeneration employees: Strategies for effective management». The Health Care Manager, 19 (1), pp. 65-76.

LEE, Y.-K., KIM, S. \& KIM, S.Y. (2013): «The Impact of Internal Branding on Employee Engagement and Outcome Variables in the Hotel Industry», Asia Pacific Journal of Tourism Research, vol. 19 (12), pp. 1.359-1.380.

MASLACH, C., SCHAUFELI, W.B. \& LEITER, M.P. (2001): «Job Burnout», Annu. Rev. Psychol., vol. 52, pp. 397-422.

MENGUC, B., AUH, S., YENIARAS, V. \& KATSIKEAS, C.S. (2017): «The role of climate: implications for service employee engagement and customer service performance», Journal of the Academy of Marketing Science, vol. 45 (3), pp. 428-451.

PAEK, S., SCHUCKERT, M., KIM, T.T. \& LEE, G. (2015): «Why is hospitality employees' psychological capital important? The effects of psychological capital on work engagement and employee morale», International Journal of Hospitality Management, vol. 50, pp. 9-26.

PARK, J. \& GURSOY, D. (2012): «Generation effects on work engagement among U.S. hotel employees», International Journal of Hospitality Management, vol. 31 (4), pp. 1.195-1.202.

RAM, P. \& PRABHAKAR, G. (2011): «The role of employee engagement in work-related outcomes», Interdisciplinary Journal of Research in Business, vol. 1(3), pp. 47-61.

SAKS, A.M. (2006): «Antecedents and consequences of employee engagement», Journal of Managerial Psychology, vol. 21 (7), pp. 600-619.

SCHAUFELI, W. (2017): Work Engagement in Europe. Relations with National Economy, Governance and Culture. Leuven.

SCHAUFELI, W.B., BAKKER, A.B. \& SALANOVA, M. (2006): «The Measurement of Work Engagement with a Short Questionnaire: A Cross-National Study», Educational and Psychological Measurement, vol. 66 (4), pp. 701-716.

SCHAUFELI, W.B., SALANOVA, M., GONZALEZ-ROMA, V. \& BAKKER, A. B. (2002): «The measurement of engagement and burnout: a two sample confirmatory factor analytic approach», Journal of Happiness Studies, vol. 3 (1), pp. 71-92.

SCHAUFELI, W. B., SHIMAZU, A., HAKANEN, J., SALANOVA, M. \& DE WITTE, H. (2017): «An Ultra-Short Measure for Work Engagement: The UWES-3 Validation Across Five Countries», European Journal of Psychological Assessment, pp. 1-15.

SHIMAZU, A., SCHAUFELI, W.B., KOSUGI, S., SUZUKI, A., NASHIWA, H., KATO, A. \& KITAOKA-HIGASHIGUCHI, K. (2008): «Work engagement in Japan: Validation of the Japanese version of the utrecht work engagement scale», Applied Psychology, vol. 57 (3), pp. 510-523.

SHUCK, B \& WOLLARD, K. (2010): «Employee engagement and HRD: A seminal review of the foundations», Human Resource Development Review, vol. 9 (1), pp. 89-110. 
SHUCK, B. (2011): «Four Emerging Perspectives of Employee Engagement: An Integrative Literature Review», Human Resource Development Review, vol. 10 (3), pp. 304-328.

SLÅTTEN, T. \& MEHMETOGLU, M. (2011): «Antecedents and effects of engaged frontline employees: A study from the hospitality industry», Managing Service Quality, vol. 21 (1), pp. 88-107.

TARIS, T.W., LE BLANC, P.M., SCHAUFELI, W.B. \& SCHREURS, P. J. G. (2005): «Are there causal relationships between the dimensions of the Maslach Burnout Inventory? A review and two longitudinal tests», Work \& Stress, vol. 19 (3), pp. 238-255.

ULUDAG, O. \& YARATAN, H. (2010): «The effect of burnout on engagement: An empirical study on tourism students», The Journal of Hospitality Leisure Sport and Tourism, vol. 9 (1), pp. 13-23.

VANCE, R.J. (2006): Employee engagement and commitment: A guide to understanding, measuring, and increasing engagement in your organization. Alexandria, VA, The SHRM Foundation.

WAGNER, R.\& HARTER, J.K. (2006): 12: The great elements of managing. Washington, D.C., The Gallup Organization. 
